\title{
Analisa Algoritma Apriori Pada Pola Peminjaman Buku di Perpustakaan ITB Ahmad Dahlan
}

\author{
Dessi Eka Sastie 1, Suparni ${ }^{2}$, Achmad Baroqah Pohan ${ }^{3, *}$ \\ ${ }^{1}$ Prodi Sistem Informasi, STMIK Nusa Mandiri, Jakarta, Indonesia \\ ${ }^{2}$ Fakultas Ekonomi dan Bisnis, Administrasi Bisnis, Universitas Bina Sarana Informatika, Jakarta,Indonesia \\ ${ }^{3}$ Fakultas Teknologi Informasi, Sistem Informasi, Universitas Bina Sarana Informatika, Jakarta, Indonesia \\ Email: ${ }^{1}$ dessiekasastie@gmail.com , ${ }^{2}$ suparni.spn@bsi.ac.id, 3,* achmad.abq@bsi.ac.id \\ *) Email Penulis Korespondensi: achmad.abq@bsi.ac.id
}

\begin{abstract}
Abstrak-Perpustakaan adalah salah satu sumber informasi dan tempat belajar. Setiap informasi peminjaman buku disimpan oleh perpustakaan sehingga menghasilkan data peminjaman buku dalam ukuran besar. Data yang besar jika tidak di manfaatkan akan membuat masalah dikemudian harinya. Dalam penelitian ini, peneliti akan memanfaatkan algoritma apriori dan bantuan software Tanagra untuk mengelompokan data peminjaman buku perpustakaan pada ITB Ahmad Dahlan berdasarkan kecenderungan yang muncul bersamaan dalam suatu kegiatan kunjungan pustaka. Dalam melakukan proses peminjaman buku, tentu saja data mentah akan diolah dengan membaginya kedalam pecahan-pecahan data yang berbeda. Diantara table data peminjaman yang diolah adalah table peminjaman secara umum, table kandidat 2-itemset, table tabular peminjaman, table nilai support, table nilai confidence. Dari hasil penelitian ini dapat diketahui apa saja buku yang sering dipinjam bersamaan dengan minimum support 5\% dan confidence $10 \%$ salah satunya adalah Akuntansi Perpajakan dan Perpajakan dengan minimum support 7,30\% confidence 62,79\%. Dan dapat dijadikan rujukan bagi pihak ITB Ahmad Dahlan dalam pengadaan dan penempatan tata letak buku perpustakaan.
\end{abstract}

Kata Kunci : Asosiasi, Algoritma Apriori, Peminjaman Buku

\begin{abstract}
The library is a source of information and a place of learning. Each book lending information is stored by the library so as to produce large data lending books. Big data if not utilized will create problems in the future. In this study, researchers will utilize a priori algorithms and Tanagra software to group library book borrowing data at Ahmad Dahlan ITB based on trends that occur together in library visit activities. In the process of borrowing books, of course the raw data will be processed by dividing it into different pieces of data. Among the lending data tables processed are general lending tables, 2 itemset candidate tables, lending tabular tables, support value tables, confidence value tables. From the results of this study it can be seen what books are often borrowed together with a minimum support of 5\% and $10 \%$ confidence one of which is Taxation and Taxation Accounting with a minimum support of $7.30 \%$ confidence $62.79 \%$. And can be used as a reference for ITB Ahmad Dahlan in the procurement and placement of library book layout.
\end{abstract}

Keywords: Association, Apriori Algorithms, Book Loans

\section{PENDAHULUAN}

Perpustakaan salah satu fasilitas penyedia ilmu pengetahuan dan informasi, perpustakaan juga menjadi salah satu tempat proses kegiatan belajar mengajar bagi para pengguna untuk mendapatkan informasi yang diinginkan. Peranan perpustakaan sangat penting dalam menyediakan buku-buku ilmiah untuk kalangan mahasiswa dan dosen[1]. Bentuk layanan yang dapat diberikan perpustakaan kepada pemustaka antara lain layanan sirkulasi atau layanan peminjaman. Dari beberapa koleksi pustaka yang ada di perpustakaan boleh dipinjam dan ada yang hanya boleh dibaca ditempat. Untuk penataan buku pada rak perpustakan seharusnya diatur sedemikian rupa untuk memberi kemudahan kepada semua pengunjung saat mencari sebuah atau beberapa buku. Kurangnya pengelolaan perpustakaan dengan baik membuat data transaksi peminjaman buku tersebut hanya disimpan begitu saja tanpa ada pengelolaan lebih lanjut. Padahal, banyaknya jumlah data transaksi peminjaman tersebut bisa digunakan untuk mengetahui aturan asosiasi antara dua buku atau lebih. Misalnya, jika anggota meminjam buku A maka juga akan meminjam buku B[2].

Pengolahan transaksi peminjaman buku dilakukan dengan pendekatan data mining. Data mining merupakan pendekatan yang dilakukan untuk mendapatkan knowledge baru dari tumpukan data berukuran besar. Teknik data mining yang digunakan adalah Association Rule. Association Rule merupakan teknik yang digunakan untuk mengetahui proses apa yang sering terjadi bersamaan. Algoritma Association Rule yang digunakan adalah algoritma apriori.[3] Fokus dari penelitian ini adalah melakukan analisa konsistensi terhadap pola peminjaman buku di Perpustakaan ITB Ahmad Dahlan dengan menggunakan algoritma apriori.

Algoritma apriori menggunakan knowledge mengenai frequent itemset yang telah diketahui sebelumnya, untuk memperoses informasi selanjutnya. Penulis menggunakan algoritma apriori karena algoritma apriori mudah dipahami dan di implentetasikan dibanding algoritma lainnya yang memang diterapkan untuk proses association rule[4]. Penerapan algoritma apriori telah banyak digunakan sebelumnya untuk mendapatkan informasi berharga dari sejumlah frekuensi data. beberapa penerapan algoritma apriori yang telah dilakukan yaitu, Penerapan Algoritma Apriori Dalam Memprediksi Persediaan Buku Pada Perpustakaan.[5] Dan Penerapan Algoritma Apriori untuk Mencari Aturan Asosiasi pada Data Peminjaman Buku di Perpustakaan.

Pada penelitian ini melihat data peminjaman buku semakin lama semakin banyak yang tidak dimanfaatkan dengan baik dan pengunjung sering merasa kesulitan dalam mencari beberapa buku yang saling 
berkaitan, memerlukan waktu yang lama karena letak buku tersebut diletakkan terpisah. Bagi staf perpustakaan sendiri merasa kesulitan dalam meletakkan buku-buku yang dikembalikan oleh pengunjung karena staf perpustakaan hanya menguasai satu bidang saja sehingga mereka tidak mengetahui buku-buku apa saja yang mempunyai relasi antara buku satu dengan yang lainnya.

\section{METODE PENELITIAN}

\subsection{Tahapan Penelitian}

Tahapan penelitian mencakup beberapa langkah yang diperlukan. Adapun penjelasan dari langkah langkah dalam penelitian untuk pembuatan skripsi ini.

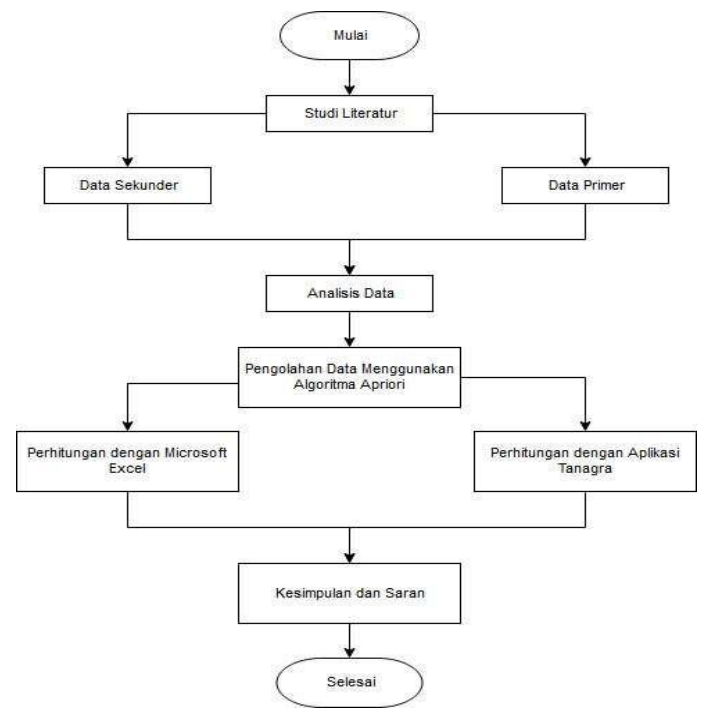

Gambar 1. Tahapan Penelitian

Adapun penjelasan tahapan pada penelitian yang akan dilakukan penulis dalam proses penelitian ini sebagai berikut:

1. Studi Literatur

Studi Literatur yang dilakukan oleh penulis yaitu dengan melakukan pencarian terhadap data dari berbagai sumber tertulis, baik berupa buku buku, jurnal atau dokumen dokumen yang sesuai dengan permasalahan yang dikaji. Sehingga informasi yang didapat dari studi literatur ini dijadikan referensi yang mendukung dan tepat untuk membahas lingkup kajian penelitian yang dilakukan.

2. Pengumpulan Data

Tahap pengumpulan data ini menggunakan dua cara yaitu :

a. Data Sekunder

Sumber data penelitian yang diperoleh melalui media perantara atau secara tidak langsung yang berupa buku, jurnal yang dipublikasikan maupun yang tidak dipublikasikan secara umum.

b. Data Primer

Sumber data penelitian yang diperoleh secara langsung dari sumber aslinya dengan cara melakukan wawancara, penulis melakukan wawancara kepada kepala UPT Perpustakaan ITB Ahmad Dahlan tentang pola peminjaman buku dan meminta laporan data peminjaman selama satu tahun dari Januari 2018 sampai Desember 2018.

3. Analisa Data

Metodologi dasar analisis asosiasi terbagi dua tahap yaitu :

a. Analisa Pola Frekuensi Tinggi

Pada tahap ini mencari kombinasi item yang memenuhi syarat minimum dari nilai support pada data transaksi. Nilai support sebuah item diperoleh dari rumus:

$$
\text { Support }=(A)=\frac{\sum \text { Transaksi yang mengandung } A}{\Gamma \text {.Transaksi }} \times 100 \%
$$

Sementara rumus 2 itemset di peroleh dengan rumus :

$$
\text { Support }=(\mathrm{A} \cap \mathrm{B})=\frac{\sum \text { Transaksi } \text { yang mengandung } \mathrm{A} \text { dan } B}{\sum \text { Transaksi }} \times 100 \%
$$

b. Pembentukan Aturan Asosias 
syarat minimum untuk confidence dengan menghitung asosiasi A ke B. Dengan menggunakan rumus Confidence yaitu:

$$
\text { Confidence }=\frac{\sum \text { Transaksi yang mengandung } A \text { dan } B}{\sum \text { Transaksi mengandung } A} \times 100 \%
$$

4. Pengolahan data menggunakan metode Apriori dan Aplikasi Tanagra

Pengolahan data ini menggunakan metode algoritma apriori yang perhitungannya dilakukan secara manual dengan cara membuat tabular kedalam Microsoft Excel, Kemudian mencari minimum support dan minimum confidence.Jika keduanya sudah memenuhi maka penulis akan membentuk aturan asosiasi final yang menjadi tujuan dari penelitian ini. Untuk menghindari kesalahan yang mungkin muncul pada saat melakukan perhitungan manual. Penulis menggunakan aplikasi Tanagra untuk melakukan pemeriksaan ulang.

5. Kesimpulan dan Saran

Membuat kesimpulan dari hasil penelitian dan memberikan saran untuk pihak perpustakaan agar dapat menjadi lebih baik lagi.

\section{HASIL DAN PEMBAHASAN}

\subsection{Analisis Data}

Metode analisis data yang digunakan dalam penelitian ini adalah metode association rules dengan algoritma Apriori. Penelitian ini akan mengikuti tahapan - tahapan Knowledge Discovery in Database (KKD) yang terdiri dari beberapa tahapan, yaitu ::

1. Data Selection

Tahapan selection merupakan tahapan pemilihan data dimana data dalam penelitian ini merupakan data peminjaman buku perpustakan ITB Ahmad Dahlan. Pada Tahapan ini yaitu menganalisa data-data yang dibutuhkan untuk dilakukan proses selanjutnya

2. Data Preprosessingclat

Tahapan preprocessing merupakan tahapan pembersihan data dari noise (gangguan) baik itu missing value maupun inkonsistenan data. Menghilangkan atribut- atribut yang tidak relevan karena keberadaannya akan mengurangi akurasi dari data mining

3. Data Transformation

Tahapan transformation merupakan tahapan dengan melakukan attribute constraction yaitu melakukan pembagian data menjadi beberapa range. Dalam penelitian ini variabel yang menggunakan range adalah judul buku

4. Data Mining

Teknik Data Mining yang dilakukan dalam proses ini adalah teknik association rules. dengan menggunakan algoritma Apriori. Algoritma apriori merupakan algoritma asosiasi yang telah banyak digunakan dan dikembangkan oleh para peneliti. Algoritma Apriori dalam menangani masalah asosiasi adalah dengan mengurangi jumlah itemset yang dipertimbangkan. Pengguna menetapkan minimum support

5. Implementasi, Pengujian dan Interpretasi Hasil

Tahapan implementasi, pengujian dan interpretasi hasil merupakan tahapan pencarian frequent itemsets dari data penelitian dan data sampel penelitian menggunakan Tanagra. Kemudian dilakukan pencarian frequent itemsets pada minimum support yang berbeda-beda. Hasil yang didapatkan dari proses sebelumnya akan diinterpretasikan menjadi informasi.

\subsection{Hasil Penelitian}

Dari hasil yang dilakukan penulis menunjukan bahwa data peminjaman buku pada ITB Ahmad Dahlan selama ini tidak dioptimalkan dengan baik, sehingga data peminjaman semakin hari semakin banyak. Data tersebut hanyan disimpan sebagai arsip atau pembukuan kampus dan tidak diketahui manfaat dari data-data yang ada tersebut.

Tabel 1. Data Peminjaman Buku 1 Tahun

\begin{tabular}{cll}
\hline No & Kode Transaksi & \multicolumn{1}{c}{ Judul Buku } \\
\hline 1 & A. Yuliana Yusuf & Manajemen SDM \\
& & Teori Ilmu Ekonomi \\
& & Perilaku Organisasi \\
2 & Abdul Akil & Akuntansi Perbankan Syariah \\
& & Perbankan Syariah \\
& & Auditing 1 \\
& & Perpajakan \\
3 & Abdul Rochman & Manajemen SDM \\
& & Metode penelitian \\
\hline
\end{tabular}




\begin{tabular}{|c|c|c|}
\hline & & Bahasa Indonesia \\
\hline \multirow[t]{5}{*}{4} & Abdurrachman & Akuntansi Biaya \\
\hline & & Auditing 1 \\
\hline & & Perpajakan \\
\hline & & Teori Akuntansi \\
\hline & & Teori Ilmu Ekonomi \\
\hline \multirow[t]{4}{*}{5} & Ade pertiwi & Manajemen SDM \\
\hline & & Metode penelitian \\
\hline & & Bahasa Indonesia \\
\hline & & Perilaku Organisasi \\
\hline \multirow[t]{4}{*}{6} & Adinda Nur Febriani & Akad dan Produk Bank Syariah \\
\hline & & Akuntansi Biaya \\
\hline & & Akuntansi Intermediate Jilid 1 \\
\hline & & Metode penelitian \\
\hline \multirow{3}{*}{370} & Zu.... & $\begin{array}{l}\text {......... } \\
\text { Bank dan Iemhaga Keuanoan I ainnya }\end{array}$ \\
\hline & & Metode penelitian \\
\hline & & Analisis laporan keuangan \\
\hline
\end{tabular}

Format Pembuatan data peminjama buku bila dibentuk akan terlihat seperti table dibawah ini :

Tabel 2. Format Pinjaman Buku

\begin{tabular}{ccccccccc}
\hline $\begin{array}{c}\text { No } \\
\text { Transaksi } \\
\text { Produk } \\
\text { Bank } \\
\text { Syariah }\end{array}$ & $\begin{array}{c}\text { Akuntansi } \\
\text { Biaya }\end{array}$ & $\begin{array}{c}\text { Akt } \\
\text { Intermediate } \\
\text { Jilid } 1\end{array}$ & $\begin{array}{c}\text { Akt } \\
\text { Internasional }\end{array}$ & $\begin{array}{c}\text { Akt } \\
\text { Prilaku }\end{array}$ & $\begin{array}{c}\text { Akuntansi } \\
\text { Keuangan } \\
\text { Lanjutan }\end{array}$ & $\begin{array}{c}\text { Akuntansi } \\
\text { Keuangan } \\
\text { Menengah }\end{array}$ & $\begin{array}{c}\text { Akuntansi } \\
\text { Manajemen }\end{array}$ \\
\hline 1 & 0 & 0 & 0 & 0 & 0 & 0 & 0 & 0 \\
2 & 0 & 0 & 0 & 0 & 0 & 0 & 0 & 0 \\
3 & 0 & 0 & 0 & 0 & 0 & 0 & 0 & 0 \\
4 & 0 & 1 & 0 & 0 & 0 & 0 & 0 & 0 \\
5 & 0 & 0 & 0 & 0 & 0 & 0 & 0 & 0 \\
6 & 1 & 1 & 1 & 0 & 0 & 0 & 0 & 0 \\
$\ldots$ & $\ldots$ & $\ldots$ & $\ldots \ldots$ & $\ldots$ & $\ldots \ldots$ & $\ldots \ldots$ & $\ldots .$. & $\ldots$ \\
370 & 0 & 0 & 0 & 0 & 0 & 0 & 0 & 0 \\
\hline
\end{tabular}

\subsection{Penerapan Algoritma Apriori}

Data peminjaman buku yang akan diteliti ialah selama 1 tahun sebanyak 370 transaksi dan 30 item buku. Pengolahan data transaksi akan dilakukan dengan beberapa tahap, yaitu sebagai berikut:

\section{Pembentukan 1 Itemset}

Sebelum dilakukan pencarian pola dari data peminjaman , dicari semua nama buku yang terdapat pada tabel transaksi untuk menentukan support per item buku, tahap ini mencari kombinasi item yang memenuhi minimum support. Maka penulis menetapkan aturan minimum support 5\% dan rumus pembentukan 1 itemset menerapkannya pada rumus 1 .

Berikut merupakan perhitungan pembentukan 1 itemset:

Persentasi jumlah item terpilih dan yang memenuhi syarat minimum support $\mathbf{= 5 \%}$ dari data transaksi dapat dilihat pada tabel dibawah ini:

Table 3. Daftar Support Setiap Itemset

\begin{tabular}{lcc}
\hline \multicolumn{1}{c}{ ITEMSET } & JUMLAH & SUPPORT \\
\hline Akad dan Produk Bank Syariah & 51 & $13.78 \%$ \\
Akuntansi Biaya & 64 & $17.30 \%$ \\
Akuntansi Intermediate Jilid 1 & 32 & $8.65 \%$ \\
Akuntansi Internasional & 31 & $8.38 \%$ \\
Akuntansi Keperilakuan & 39 & $10.54 \%$ \\
Akuntansi Keuangan Lanjutan & 29 & $7.84 \%$ \\
Akuntansi Keuangan Menengah & 46 & $12.43 \%$ \\
Akuntansi Manajemen & 38 & $10.27 \%$ \\
Akuntansi Perbankan Syariah & 45 & $12.16 \%$ \\
Akuntansi Perpajakan & 43 & $11.62 \%$ \\
Akuntansi Syariah & 42 & $11.35 \%$ \\
Analisis laporan keuangan & 81 & $21.89 \%$ \\
\hline
\end{tabular}




\begin{tabular}{lcc}
\hline Auditing 1 & 77 & $20.81 \%$ \\
$\ldots \ldots \ldots .$. & $\ldots .$. & $\ldots$. \\
Teori Ilmu Ekonomi & 36 & $9.73 \%$ \\
\hline
\end{tabular}

\section{Kombinasi 2 Itemset}

Penulis menginginkan aturan minimum support $=\mathbf{5 \%}$. Adapun rumus pembentukan 2 itemset menggunakan rumus ke 2.

Berikut adalah perhitungan pembentukan 2 itemset :

Persentasi jumlah item terpilih dan yang memenuhi syarat minimum support $=5 \%$ dari data transaksi dapat dilihat pada tabel dibawah ini:

Table 4. Daftar Support 2 Itemset

\begin{tabular}{lcc}
\hline \multicolumn{1}{c}{ Itemset } & Jumlah & Support \\
\hline Akuntansi Biaya, Auditing 1 & 21 & $5.68 \%$ \\
Akuntansi Perpajakan, Perpajakan & 27 & $7.30 \%$ \\
Akuntansi Syariah, Auditing 1 & 19 & $5.14 \%$ \\
Analisis laporan keuangan, Manajemen SDM & 21 & $5.68 \%$ \\
Analisis laporan keuangan, Metode penelitian & 35 & $9.46 \%$ \\
Auditing 1, Metode penelitian & 21 & $5.68 \%$ \\
BLKL ,Analisis laporan keuangan & 21 & $5.68 \%$ \\
BLKL ,Perilaku Organisasi & 19 & $5.14 \%$ \\
$\ldots . \ldots .$. & $\ldots .$. & $\ldots .$. \\
Teori Akuntansi,Metode penelitian & 24 & $6.49 \%$ \\
\hline
\end{tabular}

\section{Kombinasi 3 Itemset}

Untuk mendapatkan nilai akurasi yang kuat akan dilanjutkan pencarian kombinasi 3 itemset dengan minimum support 5\% dan rumu sebagai berikut

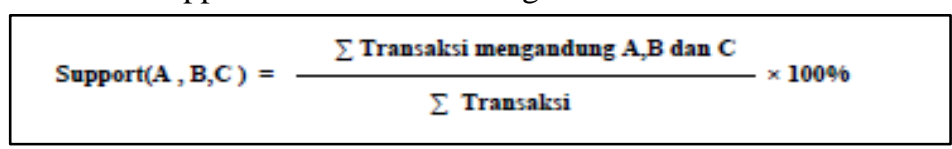

Tabel 5. Daftar Support 3 Itemset

\begin{tabular}{lcc}
\hline \multicolumn{1}{c}{ Itemset } & Jumlah & Support \\
\hline Manajemen SDM, Metopel, Perilaku Organisasi & 19 & $5,14 \%$ \\
Pengantar Akuntansi, Pengantar Akuntansi II, SIA & 2 & $0,54 \%$ \\
Perbankan Syariah, Perilaku Organisasi, TIE & 1 & $0,27 \%$ \\
Perpajakan, SIA, Manajemen SDM & 0 & $0 \%$ \\
Metopel, Pengantar Akuntansi II, Perilaku Organisasi & 1 & $0,27 \%$ \\
Manajemen SDM, Perilaku Organisasi, SIA & 1 & $0,27 \%$ \\
\hline
\end{tabular}

Karena Kombinasi 3 itemset tidak ada yang memenuhi minimal support, maka 2 kombinasi yang memenuhi untuk pembentukan Asosiasi.

4. Pembentukan Aturan Asosiasi

Setelah semua pola frekuensi tinggi ditentukan, kemudian mencari aturan asosiasi dengan hasil pola frekuensi sebagai berikut :

Tabel 6. Daftar Support 2 itemset Pembentukan Aturan Asosiasi

\begin{tabular}{lcc}
\hline \multicolumn{1}{c}{ Itemset } & Jumlah & Support \\
\hline Akuntansi Biaya, Auditing 1 & 21 & $5.68 \%$ \\
Akuntansi Perpajakan, Perpajakan & 27 & $7.30 \%$ \\
Akuntansi Syariah, Auditing 1 & 19 & $5.14 \%$ \\
Analisis laporan keuangan, Manajemen SDM & 21 & $5.68 \%$ \\
Analisis laporan keuangan, Metode penelitian & 35 & $9.46 \%$ \\
Auditing 1, Metode penelitian & 21 & $5.68 \%$ \\
BLKL, Analisis laporan keuangan & 21 & $5.68 \%$ \\
BLKL, Perilaku Organisasi & 19 & $5.14 \%$ \\
$\ldots . .$. & $\ldots$ & $\ldots$. \\
\hline
\end{tabular}

Karena hanya 2 itemset yang memenuhi syarat minimum support maka nilai confidence yang dicari dari 2 kombinasi itemset. Setelah semua pola frekuensi tinggi ditemukan, lalu mencari aturan asosiasi yang 
memenuhi syarat minimum untuk confidence dengan menghitung confidence atau asosiatif A B. Maka penulis menentukan aturan minimum confidence $=\mathbf{1 0} \%$. Nilai confidence diperoleh dengan rumus:

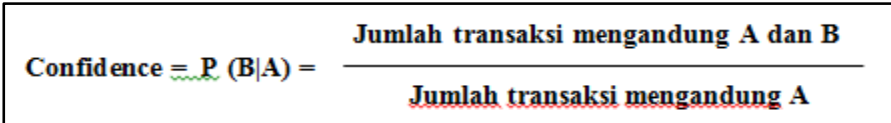

Dari kombinasi 2 itemset yang telah ditentukan, dapat dilihat besarnya nilai support dan confidence dari calon aturan asosiasi seperti pada tabel dibawah ini :

\section{Aturan Asosiasi Final}

Aturan asosiasi final berdasarkan minimal support dan minimal confidence yang telah ditntukan, maka dapat dilihat pada tabel dibawah ini :

Tabel 8. Aturan Asosiasi Final

\begin{tabular}{|c|c|c|}
\hline Aturan & Support & Confidence \\
\hline $\begin{array}{l}\text { Jika meminjam Akuntansi Biaya maka akan } \\
\text { meminjam Auditing } 1\end{array}$ & $5,68 \%$ & $32,81 \%$ \\
\hline $\begin{array}{l}\text { Jika meminjam Akuntansi Perpajakan maka akan } \\
\text { meminjam Perpajakan }\end{array}$ & $7,30 \%$ & $62.79 \%$ \\
\hline $\begin{array}{l}\text { Jika meminjam Akuntansi Syariah maka akan } \\
\text { meminjam Auditing } 1\end{array}$ & $5,14 \%$ & $45,24 \%$ \\
\hline $\begin{array}{l}\text { Jika meminjam Analisis Laporan keuangan maka } \\
\text { akan meminjam Manajemen SDM }\end{array}$ & $5,68 \%$ & $25,93 \%$ \\
\hline $\begin{array}{l}\text { Jika meminjam Analisis Laporan Keuangan maka } \\
\text { akan meminjam Metode Penelitian }\end{array}$ & $9,46 \%$ & $45,45 \%$ \\
\hline $\begin{array}{l}\text { Jika meminjam Auditing } 1 \text { maka akan meminjam } \\
\text { Metode Penelitian }\end{array}$ & $5,68 \%$ & $27,27 \%$ \\
\hline$\ldots \ldots$ & 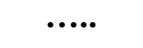 & $\cdots \cdot$ \\
\hline $\begin{array}{l}\text { Jika meminjam Metode Penelitian maka akan } \\
\text { meminjam Teori Akuntansi } 1\end{array}$ & $6,49 \%$ & $17,78 \%$ \\
\hline
\end{tabular}

\subsection{Implementasi}

\subsubsection{Perhitungan Algoritma Apriori dengan Tanagra}

Algoritma Apriori pada Tanagra dapat terbentuk dengan algoritma atau langkah-langkah yang telah ditentukan. Algoritma ini terdiri dari dua algoritma yaitu:

\section{a. Algoritma Support}

Algoritma penentuan support dapat dilihat pada Algoritma dibawah ini

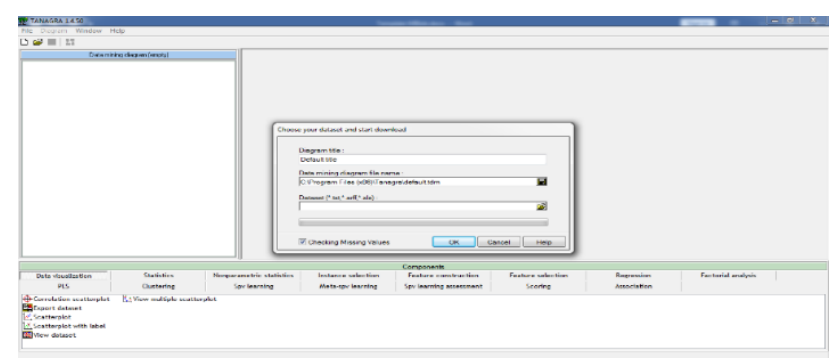

Gambar 2. Proses Pengambilan data

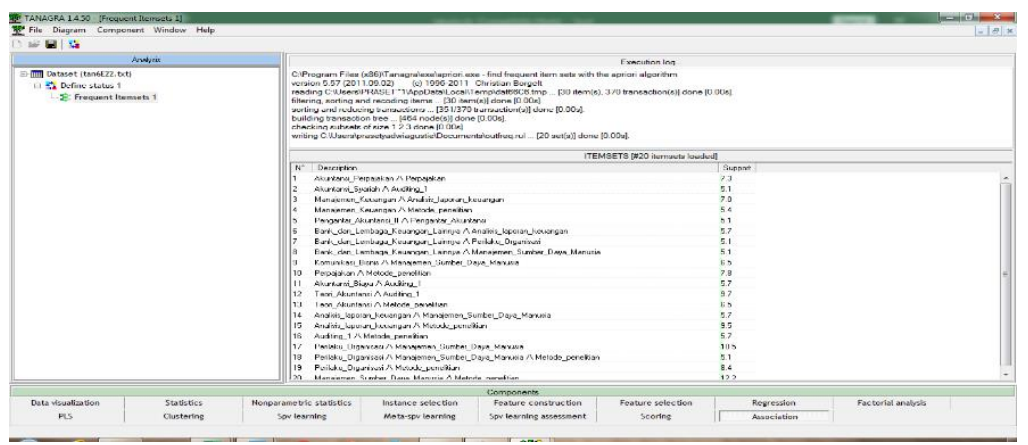

Gambar 3. Tampilan Hasil Frequents Itemset 
JURNAL MEDIA INFORMATIKA BUDIDARMA

Volume 4, Nomor 1, Januari 2020, Page 136-143

ISSN 2614-5278 (media cetak), ISSN 2548-8368 (media online)

Available Online at https://ejurnal.stmik-budidarma.ac.id/index.php/mib DOI 10.30865/mib.v4i1.1475

\section{b. Algoritma Confidence}

Algoritma penentuan confidence dapat dilihat pada Algoritma dibawah ini:

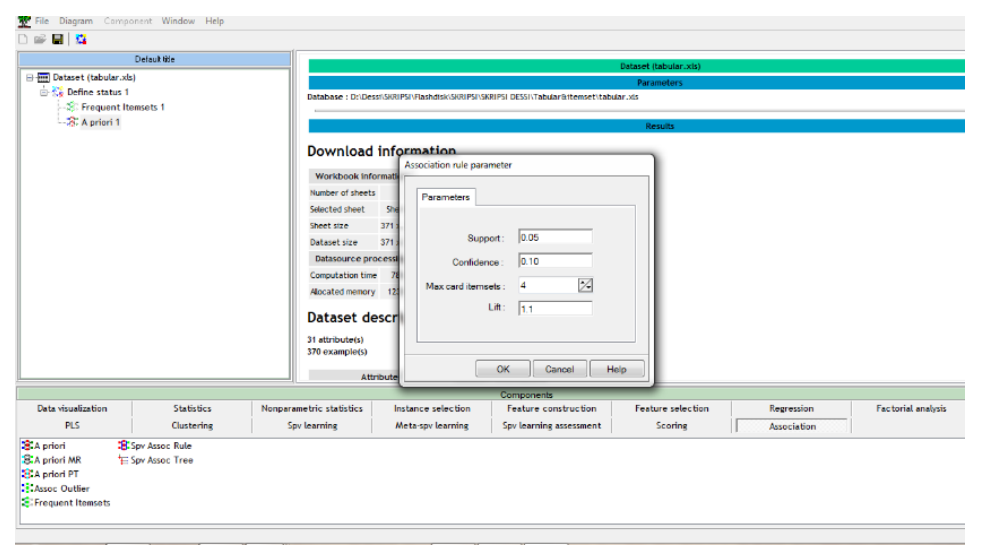

Gambar 4. Algoritma Confidence

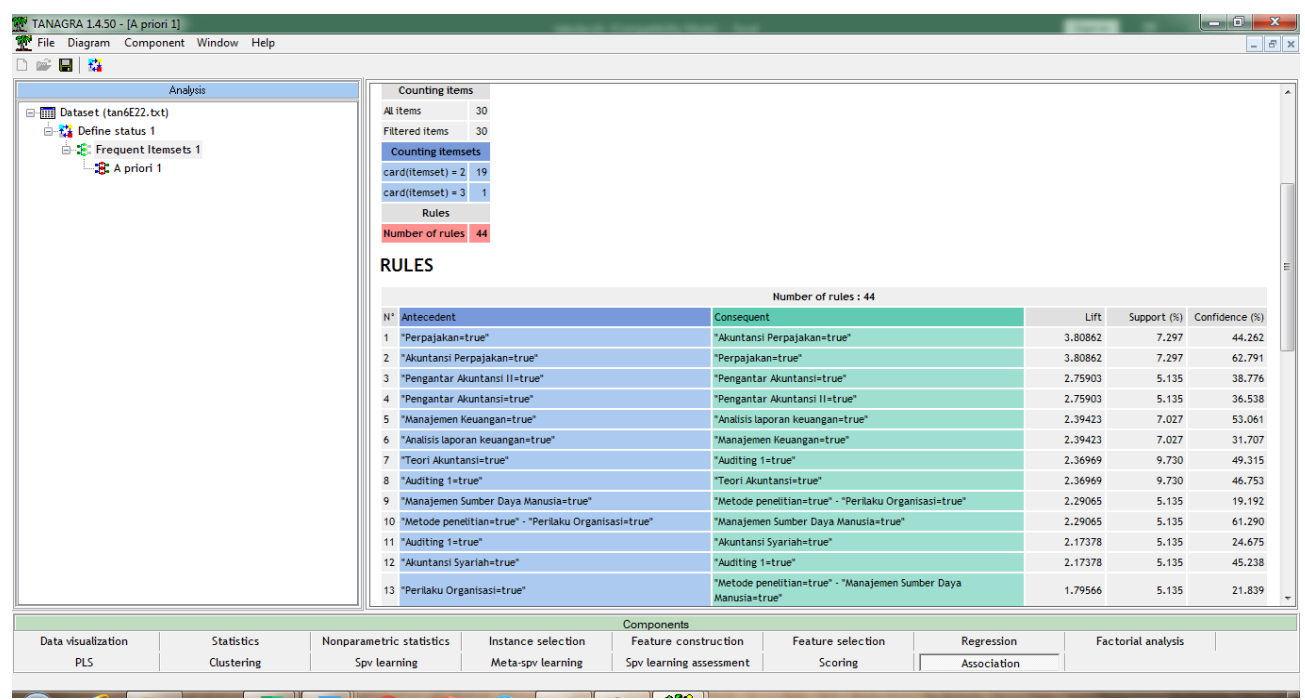

Gambar 5. Tampilan Hasil Association Rule

\section{KESIMPULAN}

Berdasarkan hasil pengujian dan analisis dari penerapan algoritma apriori dalam pola peminjaman buku pada perpustakaan ITB Ahmad Dahlan maka dapat ditarik kesimpulan sebagai berikut :

1. Algoritma apriori dapat digunakan untuk mengetahui buku apa saja yang sering muncul di dalam proses peminjaman buku.

2. Memberikan rekomendasi buku-buku terkait dengan buku yang sering dipinjam oleh pengunjung perpustakaan.

3. Dari hasil perhitungan data mining menggunakan algoritma apriori, data transaksi peminjaman buku di perpustakaan dengan batasan minimum support 5\% dan minimum confidance $10 \%$ salah satu yaitu Akuntansi Perpajakan, Perpajakan dengan nilai support 7,30\%dan nilai confidence 62,79\%, aturan tersebut berarti " $62,79 \%$ dari transaksi di data peminjaman yang memuat Akuntansi Perpajakan dan juga Perpajakan, sedangkan 7,30\%dari seluruh transaksi yang ada pada data peminjaman memuat kedua item tersebut". Artinya mahasiswa yang meminjam Akuntansi Perpajakan mempunyai kemungkinan 62,79\% untuk meminjam Perpajakan.

\section{REFERENCES}

[1] Anas, A. (2016). Analisa Algoritma Apriori Untuk Mendapatkan Pola Peminjaman Buku Perpustakaan SMPN 3 Batanghari.

[2] Anwar, S., Masukur, S., \& Jailani, M. (2019). Manajemen Perpustakaan. Riau: PT. Indragiri.

[3] Aprilina, M. N., Wiranto, \& Widodo. (2015). Analisa Konsistensi Pola Peminjaman Buku Menggunakan Algoritma FP-Growth. 


\section{JURNAL MEDIA INFORMATIKA BUDIDARMA}

Volume 4, Nomor 1, Januari 2020, Page 136-143

ISSN 2614-5278 (media cetak), ISSN 2548-8368 (media online)

Available Online at https://ejurnal.stmik-budidarma.ac.id/index.php/mib

DOI 10.30865/mib.v4i1.1475

[4] Badrul, M. (2016). Algoritma Asosiasi dengan Algoritma Apriori untuk Analisa Data Penjualan.

[5] Lingga, D. (2016). Penerapan Algoritma Apriori Dalam Memprediksi Persediaan Buku Pada Perpustakaan SMA Dwi Tunggal Tanjung Morawa.

[6] Nofriansyah, D. (2015). Konsep Data Mining vs Sistem Penunjang Keputusan. Yogyakarta: Deepublish.

[7] Rahmah, E. (2018). Akses dan Layanan Perpustakaan. Jakarta: Prenada Media.

[8] Srikanti, E., Yansi, R. F., Norhavana, Pemana, I., \& Salisah, F. N. (2018). Penerapan Algoritma Apriori Untuk Mencari Aturan Asosiasi Pada Data Peminjaman Buku Di perpustakaan.

[9] Subianto, M., AR, F., \& p, M. H. (2018). Pola Peminjaman Buku Di Perpustakaan Universitas Syiah Kuala Menggunakan Algoritma Eclat.

[10] Vulandari, T. R. (2017). Data Mining, Teori dan Aplikasi Rapidminer. Yogyakarta: Gava media. 